\title{
SIMULATIONS ON NICKEL TARGET PREPARATION AND SEPARATION OF Ni(II)- $\mathrm{Cu}(\mathrm{II})$ MATRIX FOR PRODUCTION OF RADIOISOTOPE 64Cu
}

\author{
Sunarhadijoso Soenarjo, Wira Y. Rahman, Sriyono, Triyanto \\ The Center for Radioisotopes and Radiopharmaceuticals, BATAN, Kawasan PUSPIPTEK Serpong, Tangerang. \\ e-mail : soenarjo@batan.go.id.
}

Acceptable 20 May 2010, acceptable in the correction entry 25 January 2011, agreeable 26 January 2011

\begin{abstract}
SIMULATIONS ON NICKEL TARGET PREPARATION AND SEPARATION.OF Ni(II)-Cu(II) MATRIX FOR PRODUCTION OF RADIOISOTOPE ${ }^{64} \mathrm{Cu}$. The simulations on Nickel target preparation and separation of Ni(II)$\mathrm{Cu}(\mathrm{II})$ matrix has been carried out as a preliminary study for production of medical radioisotope Cu-64 based on nuclear reaction of ${ }^{64} \mathrm{Ni}(p, n){ }^{64} \mathrm{Cu}$. The nickel target preparation was performed by means of electroplating method using acidic solution of nickel chloride - boric acid mixture and basic solution of nickel sulphate - nickel chloride mixture on a silver- surfaced-target holder. The simulated solution of Ni(II) - Cu(II) matrix was considered as the solution of post-proton-irradiated nickel target containing both irradiated nickel and radioactive copper, but in the presented work the proton irradiation of nickel target was omitted, while the radioactive copper was originally obtained from neutron irradiation of $\mathrm{CuO}$ target. The separation of radioactive copper from the nickel target matrix was based on anion exchange column chromatography in which the radiocopper was conditioned to form anion complex $\mathrm{CuCl}_{4}{ }^{2-}$ and retained on the column while the nickel was kept in the form of $\mathrm{Ni}^{2+}$ cation and eluted off from the column. The retained radioactive copper was then eluted out the column in the condition of dilute $\mathrm{HCl}$ changing back the copper anion complex into $\mathrm{Cu}^{2+}$ cation. It was found that the electroplating result from the acidic solution was more satisfied than that from the basic solution. By conditioning the matrix solution at $\mathrm{HCl} 6 \mathrm{M}$, the radioactive copper was found in the forms of $\mathrm{Cu}^{2+}$ and $\mathrm{CuCl}_{4}{ }^{2-}$ while the nickel was totally in the form of $\mathrm{Ni}^{2+}$. In the condition of $\mathrm{HCl} 9 \mathrm{M}$, the radioactive copper was mostly in the form of $\mathrm{CuCl}_{4}^{2-}$ while the nickel was found as both $\mathrm{Ni}^{2+}$ and $\mathrm{NiCl}_{4}^{2-}$. The best condition of separation was in $\mathrm{HCl} 8 \mathrm{M}$ in which the radioactive copper was mostly in the form of $\mathrm{CuCl}_{4}^{2-}$ while the nickel was mostly in the form of $\mathrm{Ni}^{2+}$. The retained $\mathrm{CuCl}_{4}{ }^{2-}$ was then changed back into $\mathrm{Cu}^{2+}$ cation form and eluted out the column by using $\mathrm{HCl} 0.05 \mathrm{M}$. The $\gamma$-spectrometric analysis showed a single strong peak at $511 \mathrm{keV}$ which is in accord to $\gamma$-annihilation peak coming from positron decay of $\mathrm{Cu}-64$, and a very weak peak at $1346 \mathrm{keV}$ which is in accord to $\gamma$-ray of $\mathrm{Cu}-64$.
\end{abstract}

Keywords : Nickel target preparation, Radioisotope Cu-64, Separation of Ni(II)-Cu(II) matrix, Nuclear reaction of ${ }^{64} \mathrm{Ni}$ $(p, n){ }^{64} \mathrm{Cu}$, Anion exchange chromatography.

\begin{abstract}
ABSTRAK
SIMULASI PREPARASI TARGET NIKEL DAN PEMISAHAN MATRIK Ni(II)-Cu(II) UNTUK PRODUKSI RADIOISOTOP ${ }^{64} \mathrm{Cu}$. Simulasi proses preparasi target nikel dan pemisahan matrik Ni(II)-Cu(II) telah dipelajari sebagai langkah awal dalam penguasaan teknologi produksi radioisotop Cu-64 melalui reaksi nuklir ${ }^{64} \mathrm{Ni}(p, n){ }^{64} \mathrm{Cu}$. Target nikel disiapkan melalui elektroplating suasana asam larutan nikel klorida - asam borat dan elektroplating suasana basa larutan nikel klorida - nikel sulfat pada keping penyangga target dengan permukaan perak. Larutan simulasi matrik Ni(II) - Cu(II) dianggap sebagai larutan target nikel pasca iradiasi yang mengandung nikel dan tembaga radioaktif, tetapi dalam percobaan ini iradiasi nikel tidak dilakukan sedangkan tembaga radioaktif dihasilkan dari aktivasi target $\mathrm{CuO}$ menggunakan berkas neutron. Pemisahan radioisotop Cu dari matrik target nikel dilakukan berdasarkan teknik kromatografi kolom penukar anion dengan mengkondisikan spesi $\mathrm{Cu}$ berada dalam bentuk komplek anion $\mathrm{CuCl}_{4}{ }^{2-}$ sedangkan spesi $\mathrm{Ni}$ berada dalam bentuk kation $\mathrm{Ni}^{2+}$. Spesi komplek anion $\mathrm{CuCl}_{4}{ }^{2-}$ yang tertahan dalam kolom resin penukar anion kemudian dielusi keluar kolom dengan mengubahnya kembali menjadi kation $\mathrm{Cu}^{2+}$ dalam kondisi $\mathrm{HCl}$ encer. Hasil percobaan menunjukkan bahwa elektroplating menggunakan larutan nikel suasana asam memberikan deposit elektroplating nikel yang lebih memuaskan dibandingkan dengan larutan nikel suasana basa. Pengkondisian larutan matrik dalam $\mathrm{HCl} 6 \mathrm{M}$ menunjukkan bahwa spesi tembaga berada dalam bentuk $\mathrm{Cu}^{2+}$ dan $\mathrm{CuCl}_{4}{ }^{2-}$, sedangkan spesi nikel dalam bentuk kation $\mathrm{Ni}^{2+}$. Dalam kondisi $\mathrm{HCl} 9 \mathrm{M}$, spesi tembaga berada dalam bentuk $\mathrm{CuCl}_{4}^{2-}$, sedangkan spesi nikel dalam bentuk $\mathrm{Ni}^{2+}$ dan $\mathrm{NiCl}_{4}{ }^{2-}$. Kondisi pemisahan yang terbaik adalah dalam $\mathrm{HCl} 8 \mathrm{M}$ yang memberikan kondisi untuk spesi tembaga berada dalam bentuk $\mathrm{CuCl}_{4}{ }^{2-}$, sedangkan spesi nikel dalam bentuk kation $\mathrm{Ni}^{2+}$. Selanjutnya spesi $\mathrm{CuCl}_{4}^{2-}$ yang tertahan di dalam kolom diubah kembali
\end{abstract}


menjadi $\mathrm{Cu}^{2+}$ dan dielusi keluar kolom dengan $\mathrm{HCl}$ 0,05 M. Pemeriksaan spektrometri- $\gamma$ menunjukkan puncak kuat pada energi $511 \mathrm{keV}$ yang sesuai dengan energi radiasi zanihilasi radioisotop ${ }^{64} \mathrm{Cu}$ dan puncak lemah pada 1346 $\mathrm{keV}$ yang sesuai dengan energi radiasi $\gamma$ dari radioisotop ${ }^{64} \mathrm{Cu}$.

Kata kunci : Pembuatan target nikel, Radioisotop ${ }^{64} \mathrm{Cu}$, Pemisahan matrik Ni(II)-Cu(II), Reaksi nuklir ${ }^{64} \mathrm{Ni}(p, n){ }^{64} \mathrm{Cu}$, Kromatografi penukar anion.

\section{INTRODUCTION}

adioisotope ${ }^{64} \mathrm{Cu}$ has a half-life of about 12.7 hours and decays by various ways, i.e. : positron emission $(17.86 \%)$, beta decay $(39.0 \%)$, electron capture $(43.075 \%)$ and internal conversion $(0.475 \%)$, emitting $0.5787 \mathrm{MeV}$ of $\beta^{-}, 0.6531 \mathrm{MeV}$ of $\beta^{+}$and $1.34577 \mathrm{MeV}$ of $\gamma$ radiations ${ }^{[1]}$. It has been known as medical radioisotope widely used in the form of various radiopharmaceuticals for both diagnostic and therapeutic purposes due to its emitted $\gamma$-annihilation and $\beta^{-}$radiations ${ }^{[2-6]}$. However, the potency of the application of this radioisotope has not been able to be expoloited at the domestic nuclear medicine facilities, mostly due to the lack of technical capabilities on the production of the radioisotope and its radiopharmaceuticals.

Radioisotope ${ }^{64} \mathrm{Cu}$ can be produced in a reactor or cyclotron. In a reactor, ${ }^{64} \mathrm{Cu}$ is obtained using either thermal or fast neutrons via $(n, \gamma)$ or $(n, p)$ reaction on ${ }^{63} \mathrm{Cu}$ or ${ }^{64} \mathrm{Zn}$ targets respectively. The method based on simple nuclear reaction of ${ }^{63} \mathrm{Cu}(\mathrm{n}, \gamma){ }^{64} \mathrm{Cu}$ even though using a high-enriched ${ }^{63} \mathrm{Cu}$ target will produce a low specific activity of ${ }^{64} \mathrm{Cu}$ which is not suitable for medical applications. The $(n, p)$ nuclear reaction on high-enriched ${ }^{64} \mathrm{Zn}$ target is another alternative method for producing ${ }^{64} \mathrm{Cu}$ in a nuclear reactor ${ }^{[7]}$. This method needs fast neutron fraction but the irradiation facility for the fast neutron fraction is not available in BATAN's G.A. Siwabessy reactor. Study on this reaction in BATAN's G.A. Siwabessy reactor, therefore, has a problem related to the formation of ${ }^{65} \mathrm{Zn}$ as the main produced radionuclide from the $(n, \gamma)$ reaction which will be produced in higher yield than the expected ${ }^{64} \mathrm{Cu}$. The nuclear reactions based on bombardment using proton beam in cyclotron is accordingly preferred to produce carrier-free ${ }^{64} \mathrm{Cu}$ suitable for medical purposes. The nuclear reaction of ${ }^{68} \mathrm{Zn}$ $(p, \alpha n){ }^{64} \mathrm{Cu}$ has been studied and reported by Bonardi et $a l^{[8]}$, but this method needs a high energy of the proton beams (more than $30 \mathrm{MeV}$ ) those are not suitable with the BATAN's cyclotron machine. The nuclear reaction of ${ }^{64} \mathrm{Ni}(\mathrm{p}, \mathrm{n}){ }^{64} \mathrm{Cu}^{[9,10]}$ which needs a lower energy of proton beams those are available in BATAN's cyclotron machine (less than $25 \mathrm{MeV}$ ) might be a better choice, although the high-enriched ${ }^{64} \mathrm{Ni}$ is very expensive due to its very low natural abundance (only $0.926 \%)^{[11]}$.

As a preliminary step to master production technology of ${ }^{64} \mathrm{Cu}$, the presented work is aimed to study the separation of radioactive copper from a matrix of proton irradiated natural nickel as the target material instead of the high-enriched ${ }^{64} \mathrm{Ni}$. The target material can be provided as electroplated deposit on silver-surface-target holder that is suitable for proton irradiation in the BATAN's Cyclotron Facility. Based on the nuclear reaction of ${ }^{64} \mathrm{Ni}(\mathrm{p}, \mathrm{n}){ }^{64} \mathrm{Cu}$, the radionuclidic separation of ${ }^{64} \mathrm{Cu}$ from the matrix of $\mathrm{Ni}$ target by means of ion exchange column chromatography was studied.

It has been known that the chemical matrix of $\mathrm{Ni}(\mathrm{II})-\mathrm{Cu}(\mathrm{II})$ mixture can be separated by using Dowex anion exchange resin based on the ability of $\mathrm{Cu}(\mathrm{II})$ in forming a chloro-complex anion at a certain condition in which the $\mathrm{Ni}(\mathrm{II})$ is still in the form of $\mathrm{Ni}^{2+}$ cation ${ }^{[12]}$. The chloro-complex anion of $\mathrm{Cu}(\mathrm{II})$ is thus expected to be bound on the anion exchanger resin while the $\mathrm{Ni}(\mathrm{II})$ cation is not, so that the later can be easily eluted out from the column. Due to technical and economical reasons, the presented work was carried out by using unirradiated natural nickel target, while the radioactive copper was simulated using neutron-irradiated natural $\mathrm{CuO}$. The result of this presented work is expected to be applicable for routine procedure in separation of radioisotope ${ }^{64} \mathrm{Cu}$ from the matrix of proton-irradiated $\mathrm{Ni}$ target based on nuclear reaction of ${ }^{64} \mathrm{Ni}(p, n){ }^{64} \mathrm{Cu}$.

\section{EXPERIMENTAL}

\section{Material and equipment}

All chemical materials were pro analysis grade and used without further purifications. Copper oxide $(\mathrm{CuO})$, nickel chloride $\left(\mathrm{NiCl}_{2} \cdot 6 \mathrm{H}_{2} \mathrm{O}\right)$, hydrochloric acid $(\mathrm{HCl})$, dimethyl glyoxime $(\mathrm{DMG})$ were produced by E.Merck, while Dowex AG 1X8 $\left(\mathrm{Cl}^{-}\right)$was obtained from Bio-Rad. De-mineralized water (aqua DM) was obtained 
from the Water Purification Facility at the Center of Multi Purpose Reactor, BATAN, Serpong. Quartz tubes of neutron-irradiation grade used as irradiation ampoules, as well as alumunium capsules for irradiation, which were made of highly pure aluminium, were supplied by local private company. For obtaining ${ }^{64} \mathrm{Cu}$, an appropriate amount of $\mathrm{CuO}$ was irradiated in the rabbit system of the G.A. Siwabessy reactor (BATAN, Serpong).

Separation of $\mathrm{Ni}(\mathrm{II})-\mathrm{Cu}(\mathrm{II})$ matrix by means of ion exchange column chromatography was performed using Econo-column 737-1010 (Bio-Rad USA). A gamma-spectrometry system equipped with a multi channel analyzer (Canberra 1000) and an HP-Ge detector (Canberra Industries) was used for radionuclidic analysis. Prior to its use, the spectrometer was calibrated using standard sealed-sources of ${ }^{133} \mathrm{Ba}(302.85$ and $356.01 \mathrm{keV})$, ${ }^{137} \mathrm{Cs}(661.64 \mathrm{keV})$ and ${ }^{60} \mathrm{Co}$ (1173.23 and $1332.51 \mathrm{keV}$ ) from Du Pont ${ }^{[13]}$. A well-type dose calibrator (Atom Lab) was used for radioactivity measurement.

\section{Preparation and dissolution of Nickel target}

Two types of electroplating solution of nickel target were prepared by adopting procedures written by Kopeliovich ${ }^{[14]}$. The first was by dissolving $20.24 \mathrm{~g}$ of NiCl $2.6 \mathrm{H}_{2} \mathrm{O}$ and $4.5 \mathrm{~g}$ of $\mathrm{H}_{3} \mathrm{BO}_{3}$ in about $100 \mathrm{~mL}$ of water giving the $\mathrm{pH}$ of solution less than 3 . It was then followed by dilution to $150 \mathrm{~mL}$ with water. The second electroplating solution was prepared by dissolving $40 \mathrm{~g}$ of NiSO${ }_{4} \cdot 6 \mathrm{H}_{2} \mathrm{O}$ and $5 \mathrm{~g}$ of $\mathrm{NiCl}_{2} \cdot 6 \mathrm{H}_{2} \mathrm{O}$ in about $100 \mathrm{~mL}$ of water, followed by $\mathrm{pH}$ adjustment to more than 7 by addition of $\mathrm{NH}_{4} \mathrm{OH}$ solution. The solution was finally diluted to $150 \mathrm{~mL}$ with water. The resulting solutions were transferred into a closed polyethylene bottle and kept as nickel-electroplating solutions until used.

Preparation of target was carried out by electroplating of the nickel solution on a silver-surface-target holder. A known-weight-silver-surface-target holder was placed as a side wall of the electroplating cell as shown in Figure 1, and functioned as a cathode. A piece of Pt-anode was placed at another side of the cell. The nickelelectroplating solution was then poured into the electroplating cell, and the electroplating steps were performed by applying varieties of currents. After finishing the electroplating, the solution was retransferred into the header by means of vacuum pressure. The target holder was released from the cell, rinsed with water and dried before being weighed to measure the amount of the resulting nickel deposit. The target was ready to be irradiated with a proton beam in cyclotron irradiation facility, but in case of this simulation procedure, the irradiation step was omitted.

For the dissolution of the nickel target, the target holder, which has the electroplated nickel on its surface, was placed as the bottom of the dissolution cell. About $10 \mathrm{~mL} \mathrm{of} \mathrm{HCl}$ (varieties in molarities) was then transferred into the dissolution cell. The cell was then heated for up to $80-90^{\circ} \mathrm{C}$ with occasionally shaking. Fews drops of $\mathrm{H}_{2} \mathrm{O}_{2}$ were added to speed the dissolution process. The resulting nickel solution was then transferred into the header by vacuum pressure and then transferred into receiving bottle for further process (namely Solution I).

\section{Neutron irradiation and dissolution of Copper target}

An amount of about $50 \mathrm{mg}$ of $\mathrm{CuO}$ powder was placed in a quartz irradiation ampoule. The ampoule was then closed by welding and placed in an inner aluminium capsule. The inner capsule was then closed by welding and sent into rabbit system facility of the G.A. Siwabessy reactor for irradiation. The irradiation was performed for about 1 hour after which the irradiated $\mathrm{CuO}$ target was brought into a receiving hot cell. The quartz ampoule was then removed from the inner aluminium capsule, transferred into processing glove box and broken at the tip to transfer its content (post-irradiated $\mathrm{CuO}$ ) into a $100 \mathrm{~mL}$ glass beaker. The irradiated $\mathrm{CuO}$ was then dissolved in $10 \mathrm{~mL}$ of $\mathrm{HCl}$ (varieties in molarities). The resulting solution was named as Solution II and cited for radioactivity measurement and $\gamma$-spectrometric analysis. For further separation experiment, this solution was mixed in an equal volume with the Solution I to get simulated matrix solution of post-irradiated nickel target containing radioactive copper.

\section{Separation of ${ }^{64} \mathrm{Cu}$ from the simulated $\mathrm{Ni}$ (II) - $\mathrm{Cu}$ (II) matrix solution}

As this work is aimed to study separation technique for irradiated target matrix based on nuclear reaction of ${ }^{64} \mathrm{Ni}(p, n){ }^{64} \mathrm{Cu}$, the simulated solution of $\mathrm{Ni}(\mathrm{II})-\mathrm{Cu}(\mathrm{II})$ matrix was considered as the solution of post-protonirradiated nickel target containing both irradiated nickel and radioactive copper. In the presented work the proton 
irradiation of nickel target was omitted, while the radioactive copper was originally obtained from neutron irradiation of $\mathrm{CuO}$ target.

The solution of nickel target (Solution I) was mixed with the solution of post-irradiated copper target (Solution II) in equal volume composition (5 mL each). The $10 \mathrm{~mL}$ of resulting solution mixture was loading into chromatographic-Econo-column 737-1010 containing $4 \mathrm{~cm}$-height of pre-conditioned-Dowex 1 X8 (Cl- $100-200$ mesh) anion exchanger resin in corresponding to the effluent to be used. The eluting fraction of the loaded matrix solution was collected in the waste receiver. The column was then eluted with $1 \times 10 \mathrm{~mL}$ of concentrate $\mathrm{HCl}$ (molarities were varied in corresponding to that of the loaded solution) followed by further elution using $2 \times 5 \mathrm{~mL}$ of $0.05 \mathrm{M} \mathrm{HCl}$. Each eluate fraction was subjected to radioactivity measurement and $\gamma$-spectrometric analysis.

\section{Radioactivity measurement and radionuclidic analysis}

The radioactivity measurement was carried out using a well-type dose calibrator. To simplify the measurement procedure, the geometric consideration was ignored. Radionuclidic analysis was conducted to the Solution II (post-neutron-irradiated $\mathrm{CuO}$ ) and the resulting dilute $\mathrm{HCl}$. fractions (retrieved from the column after eluting it with $\mathrm{HCl} 0.05 \mathrm{M}$ ). A 5 to $20 \mu \mathrm{L}$ of sample was pipetted out, spotted and absorbed on 2-cm-diameter filter paper. The filter paper was dried and put into a small plastic bag and then counted at the energy range of $150-1600 \mathrm{keV}$ by using a calibrated $\gamma$-spectrometer to gain the $\gamma$-ray spectra.

\section{Chemical analysis}

The chemical analysis was performed to see whether the radioactive copper fraction was chemically contaminated with nickel. An aliquot of the sample solution was spotted on a piece of filter paper followed by spotting solution of $1 \%$ DMG in acidic ethanol and then the paper was held over ammonia vapour. A red spot or colouration was produced for a positive test result ${ }^{[15]}$.

\section{RESULTS AND DISCUSSION}

Natural nickel comprises five isotopes ${ }^{[11]}$. Their natural abundance, $(n, \gamma)$ and $(p, n)$-nuclear reactions and products are shown in Table 1. There are three radioisotopes and two stable isotopes of nickel those can be produced by $(n, \gamma)$-nuclear reaction on natural nickel target and five isotopes by the $(p, n)$-nuclear reaction. However, based on the combination of natural abundance and half-life of the corresponding produced radioisotopes, the ${ }^{64} \mathrm{Cu}$ will be expected to be the most dominant product compared to the others. There is no radioactive nickel would be worried to contaminate the resulting radioactive copper.

From the $(n, \gamma)$-nuclear reaction, the production of longer half-life nickel radioisotopes $\left({ }^{59} \mathrm{Ni}\right.$ and $\left.{ }^{63} \mathrm{Ni}\right)$ will be insignificant in the applied duration time of irradiation, whereas the shorter half-life of nickel radioisotope $\left({ }^{65} \mathrm{Ni}\right)$ will quickly decay and almost none will be left by the end of the process. From the $(p, n)$-nuclear reaction, the producing copper radioisotopes, except the ${ }^{64} \mathrm{Cu}$, have short half-lives so that it can be expected that the ${ }^{64} \mathrm{Cu}$ radioisotope is the only radioactive copper that is important to be considered. Based on the above-mentioned reasons, this presented study omitted the irradiation of nickel, neither by neutron nor proton, while the ${ }^{64} \mathrm{Cu}$ was obtained from ${ }^{\mathrm{NAT}} \mathrm{Cu}(\mathrm{n}, \gamma){ }^{64} \mathrm{Cu}$ instead of ${ }^{\mathrm{NAT}} \mathrm{Ni}(\mathrm{p}, n){ }^{64} \mathrm{Cu}$ nuclear reaction. In the other side of view, the natural Cu comprises two isotopes, ${ }^{63} \mathrm{Cu}$ and ${ }^{65} \mathrm{Cu}$, with the abundance of $69.17 \%$ and $30.83 \%$ respectively. The later will produce ${ }^{66} \mathrm{Cu}$ on $(n, \gamma)$-nuclear reaction that can be ignored during this study because its half-life is only 5.12 minutes ${ }^{[11]}$.

Table 1. The natural isotopes of nickel and their $(n, \gamma)$ and $(p, n)$-nuclear reactions product.

\begin{tabular}{|c|c|c|c|c|c|c|c|}
\hline \multirow{2}{*}{ ISOTOPE } & \multirow{2}{*}{$\begin{array}{c}\text { ABUNDANCE } \\
(\%)\end{array}$} & \multicolumn{3}{|c|}{$(\mathrm{n}, \gamma)$-PRODUCT } & \multicolumn{3}{|c|}{$(\mathrm{p}, \mathrm{n})$-PRODUCT } \\
\cline { 3 - 8 } & & ISOTOPE & $\mathrm{t}_{1 / 2}$ & $\mathrm{E}_{\gamma}(\mathrm{keV})$ & ISOTOPE & $\mathrm{t}_{1 / 2}$ & $\mathrm{E}_{\gamma}(\mathrm{keV})$ \\
\hline \hline${ }^{58} \mathrm{Ni}$ & 68.077 & ${ }^{59} \mathrm{Ni}$ & $7.5 \times 10^{4} \mathrm{a}$ & No $\gamma$ & Cu-58 & $3.2 \mathrm{~s}$ & 511,1454 \\
\hline${ }^{60} \mathrm{Ni}$ & 26.223 & ${ }^{61} \mathrm{Ni}$ & stable & -- & Cu-60 & $23 \mathrm{~m}$ & 511,1332 \\
\hline${ }^{61} \mathrm{Ni}$ & 1.140 & ${ }^{62} \mathrm{Ni}$ & stable & -- & Cu-61 & $3.4 \mathrm{~h}$ & 511,283 \\
\hline${ }^{62} \mathrm{Ni}$ & 3.634 & ${ }^{63} \mathrm{Ni}$ & $100 \mathrm{a}$ & No $\gamma$ & Cu-62 & $9.74 \mathrm{~m}$ & 511,1173 \\
\hline${ }^{64} \mathrm{Ni}$ & 0.926 & ${ }^{65} \mathrm{Ni}$ & $2.52 \mathrm{~h}$ & 1481 & $\mathrm{Cu}-64$ & $12.7 \mathrm{~h}$ & 511,1346 \\
\hline
\end{tabular}

NOTE : All of copper radioisotopes produced by $(p, n)$-nuclear reaction on natural nickel are $\beta^{+}$-emitters, so they release annihilation radiation observed as $\gamma$-ray at $511 \mathrm{keV}$. 
The electroplating method is the most suitable technique in solid target preparation for irradiation in BATAN's Cyclotron facility. In the presented work, the nickel electroplating was performed based on the method reported by Kopeliovich ${ }^{[14]}$. The electroplating cell and the silver-surface-target holder systems used were similar to those for preparation of thallium target in production of ${ }^{201} \mathrm{Tl}^{[16]}$ as shown in Figure 1. The results of repeated electroplating procedures with varieties conditions are resumed in Table 2.

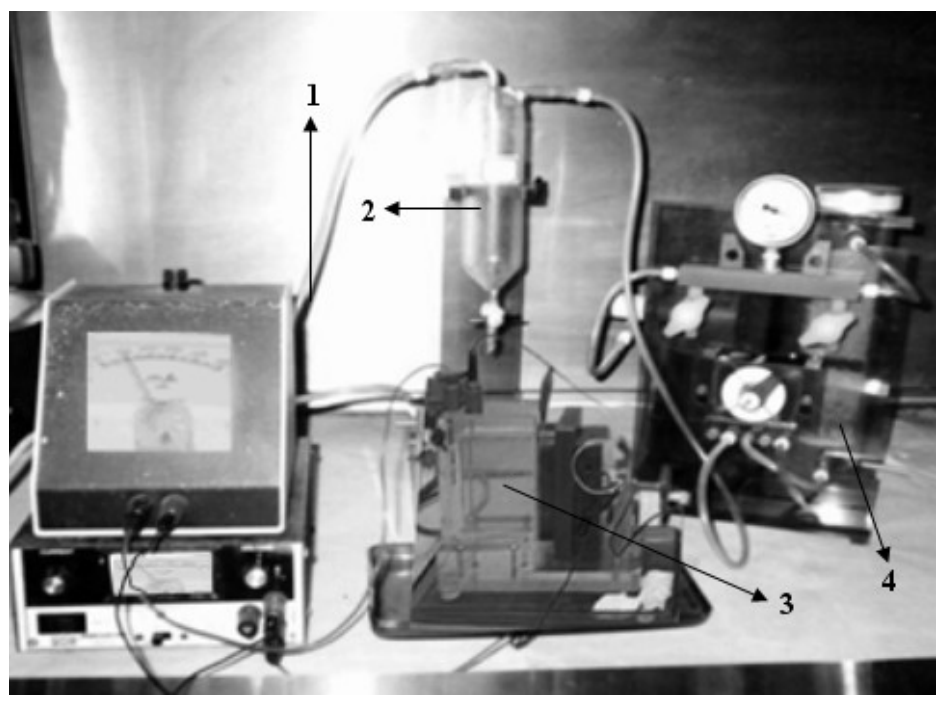

Figure 1. Nickel electroplating cell with supporting devices. 1. Volt and ampere meter, 2. Header for solution, 3. Electroplating cell containing nickel solution with target holder at the right side, 4. Mini vacuum pump,

It can be seen from Table 2 that the better conditions for nickel electroplating were found to be using the electroplating solution of $\mathrm{pH}<3$ (containing boric acid and nickel chloride) and the applied current of $100-120$ $\mathrm{mA}$. This result was then used for further experiments. The resulting nickel deposits were dissolved in varieties molarities of $\mathrm{HCl}$ those are corresponding to molarities of $\mathrm{HCl}$ used for simulation of column chromatographic separation.

The simulated solution of post-proton-irradiated nickel must contain both nickel (as target material) and radioactive copper (as the result of proton irradiation on nickel target). Accordingly, a $10 \mathrm{~mL}$ of matrix solution containing equal volume of Solution I (nickel target solution) and Solution II (post-irradiated copper solution) was loaded into the anion exchanger column. The separation fractions comprised three eluates, i.e. $1 \times 10 \mathrm{~mL}$ of waste, $1 \times 10 \mathrm{~mL}$ of concentrate $\mathrm{HCl}$ (varieties in molarities) and $2 \times 5 \mathrm{~mL}$ of $\mathrm{HCl} 0.05 \mathrm{M}$. The distributions of radioactive copper in the resulting fractions are summarized in Table 3.

Table 2. Electroplating result in simulation of nickel target preparation ${ }^{11}$.

\begin{tabular}{|c|c|c|c|c|c|}
\hline No. & $\begin{array}{c}\text { Current } \\
(\mathrm{mA})\end{array}$ & $\mathrm{pH}$ & $\begin{array}{c}\text { Amount of } \\
\text { deposited } \mathrm{Ni}(\mathrm{mg})\end{array}$ & $\begin{array}{c}\text { Deposit thickness } \\
\left(\mathrm{mg} / \mathrm{cm}^{2}\right)\end{array}$ & Remark on the resulting deposit \\
\hline 1. & 100 & $>7$ & 430.0 & 30.71 & \multirow{3}{*}{$\begin{array}{l}\text { Bad fluctuation, bad quality of surface, mechanically } \\
\text { unstable }\end{array}$} \\
\hline 2. & 100 & $>7$ & 180.0 & 12.86 & \\
\hline 3. & 100 & $>7$ & 323.0 & 23.07 & \\
\hline 4 & 80 & $<3$ & 366.3 & 26.16 & $\begin{array}{l}\text { Needs longer time to get suitable thickness, unstable } \\
\text { current }\end{array}$ \\
\hline 5 & 100 & $<3$ & 443.6 & 31.69 & \multirow{4}{*}{$\begin{array}{l}\text { Good fluctuation, good quality of surface, mechanically } \\
\text { stable, the applied current was more stable }\end{array}$} \\
\hline 6 & 100 & $<3$ & 417.9 & 29.85 & \\
\hline 7 & 120 & $<3$ & 526.8 & 37.63 & \\
\hline 8 & 120 & $<3$ & 499.9 & 35.71 & \\
\hline 9 & 140 & $<3$ & 587.9 & 41.99 & \multirow[t]{2}{*}{ Bad quality of surface, mechanically unstable } \\
\hline 10 & 160 & $<3$ & 680.4 & 48.60 & \\
\hline
\end{tabular}

NOTE : 1). All electroplating procedures were performed for 5 hours. 
Table 3. Distribution of radioactive copper in the resulting separation fractions

\begin{tabular}{|l|c|c|c|c|c|}
\hline Molarities of $\mathrm{HCl}$ used to dissolve the target & $6 \mathrm{M}$ & \multicolumn{3}{|c|}{$8 \mathrm{M}$} & $9 \mathrm{M}$ \\
\hline Volume of matrix solution loaded into the column (mL) & 10 & 10 & 10 & 10 & 10 \\
\hline Radioactivity of matrix solution loaded into the column (mCi & 249 & 8.97 & 2.54 & 2.50 & 0.741 \\
[\%]) & {$[100]$} & {$[100]$} & {$[100]$} & {$[100]$} & {$[100]$} \\
\hline Distribution of radioactivity after loading the matrix solution & & & & & \\
$\quad$ Column (\%) & 96.79 & 99.55 & 98.43 & 98.80 & 93.25 \\
$\quad$ Eluate (\%) & 0.23 & 0.11 & 0.50 & 1.61 & 6.33 \\
$\quad$ Activity loss (Error, \%) & +2.98 & +0.34 & +1.07 & -0.41 & +0.42 \\
\hline Distribution of radioactivity after eluting the column with & & & & & \\
corresponding concentrate HCl & & & & & \\
(6 M, 8 M or 9 M) & & & & & \\
Column (\%) & 65.74 & 87.63 & 80.71 & 97.20 & 90.28 \\
Eluate (\%) & 29.56 & 9.96 & 15.28 & 2.80 & 8.07 \\
$\quad$ Activity loss (Error, \%) & +1.49 & +1.96 & +2.44 & -1.20 & -5.10 \\
\hline Distribution of radioactivity after eluting the column with dilute & & & & & \\
HCl (0.05 M, 2 5 mL) & & & & & \\
Column (\%) & 0.38 & 3.68 & 0.41 & 26.48 & 13.17 \\
$\quad$ Eluate-I (\%) & 62.97 & 74.92 & 77.89 & 68.03 & 77.60 \\
Eluate-II (\%) & 0.21 & 0.21 & 0.51 & 1.63 & 6.73 \\
$\quad$ Activity loss (Error, \%) & +2.18 & +8.82 & +1.90 & +1.06 & -7.22 \\
\hline
\end{tabular}

The resulting data summarized in Table 3 were found to be unsatisfactory in term of statistical precision and accuracy. This was suspected because of the geometric of samples measurement that was not taken into consideration. Nevertheless, the qualitative trend of separation is consistent in which the radioactive copper was bound on the anion exchanger at the condition of concentrate $\mathrm{HCl}(8 \mathrm{M}$ and $9 \mathrm{M})$ due to the formation of anion complex of $\mathrm{CuCl}_{4}{ }^{2-}$ and then eluted off the column by elution using dilute $\mathrm{HCl}(0.05 \mathrm{M})$ because the anion complex changes back into $\mathrm{Cu}^{2+}$ cation. In the condition of $\mathrm{HCl} 6 \mathrm{M}$, both ionic species of copper are maybe formed $^{[17]}$ so that the radioactive copper is significantly observed in both column and $\mathrm{HCl} 6 \mathrm{M}$ eluate. The observed phenomena can be explained as below :

1. $\mathrm{Cu}^{2+}{ }_{(\text {aq) }}+4 \mathrm{HCl}_{(8 \mathrm{M} \mathrm{or} 9 \mathrm{M})} \rightarrow \mathrm{CuCl}_{4}^{2-}{ }_{\text {(aq) }}+4 \mathrm{H}_{(\text {aq) }}^{+}$

2. $\mathrm{CuCl}_{4}^{2-}{ }_{(\mathrm{aq})}+2$ Dowex-(Cl- $) \rightarrow[\text { Dowex }]_{2-}\left(\mathrm{CuCl}_{4}^{2-}\right)+2 \mathrm{Cl}^{-}$(aq)

3. [Dowex] $]_{2}-\left(\mathrm{CuCl}_{4}^{2-}\right)+2 \mathrm{HCl}_{(0.05 \mathrm{M})} \rightarrow 2$ Dowex-(Cl') $+\mathrm{Cu}_{(\text {aq) }}^{{ }^{2+}}+4 \mathrm{Cl}^{-}{ }_{(\mathrm{aq})}+2 \mathrm{H}^{+}{ }_{(\mathrm{aq})}$.

The above-mentioned phenomena seem to agree with the published data presented by Jentzsch and Frotsher showing that copper will form anion complex in $\mathrm{HCl}$ with concentration of higher than $4 \mathrm{~N}$ but not in $\mathrm{HCl}$ with concentration of lower than $1.5 \mathrm{~N}^{[12]}$. In other report, Wanty et $\mathrm{al}^{[17]}$ stated that in the condition of $\mathrm{HCl} 7 \mathrm{M}$, copper species can be in the form of $\mathrm{CuCl}_{2}$ or $\mathrm{CuCl}_{4}{ }^{2-}$. Therefore, in the condition of $\mathrm{HCl} 6 \mathrm{M}$ the copper spesies can be in the forms of both cationic and anionic species.

Table 4. DMG-spot test analysis on separated eluate fraction.

\begin{tabular}{|l|c|c|c|c|c|}
\hline Molarities of $\mathrm{HCl}$ used to dissolve the target & $6 \mathrm{M}$ & \multicolumn{3}{|c|}{$8 \mathrm{M}$} & $9 \mathrm{M}$ \\
\hline Color visualization on the concentrate $\mathrm{HCl}$ eluat & Green & Green & Green & Green & Greenish pale \\
\hline DMG spot test on $\mathrm{HCL} 0,05 \mathrm{M}$ fraction & - & - & - & - & + \\
\hline
\end{tabular}



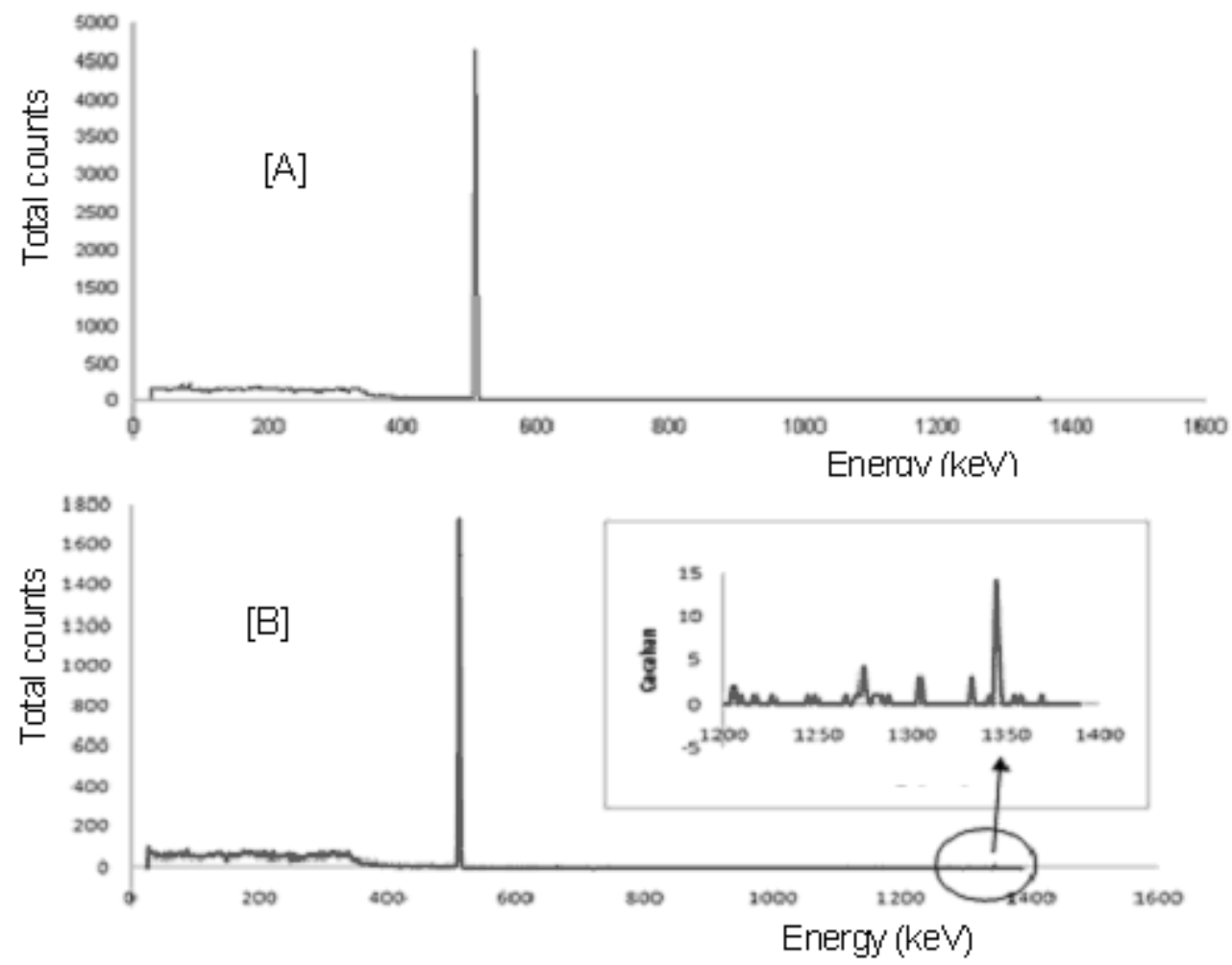

Figure 2. Typical $\gamma$-spectra of post-neutron-irradiated $\mathrm{CuO}$ solution $[\mathrm{A}]$ and radioactive copper fractions in $\mathrm{HCl}$ $0.05 \mathrm{M}[\mathrm{B}]$.

On the other side, the nickel will be in the form of anion complex in $\mathrm{HCl}$ with concentration between 10 to $11 \mathrm{~N}$. In HCl with concentration of less than $7.5 \mathrm{~N}$, however, the anion complex of nickel is not formed ${ }^{[12]}$. Accordingly, it can be expected that the nickel is not trapped on the anion exchanger in the condition of $\mathrm{HCl}$ with a concentration of less than $7.5 \mathrm{M}$. In order to check the existence of nickel in the eluted radioactive copper fractions, the dimethylglyoxime (DMG) spot test was then applied. The result of spot test by using DMG in the $\mathrm{HCl} 0.05 \mathrm{M}$ fractions which were assumed to contain radioactive copper is summarized in Table 4.

The spot test data indicate that in either $\mathrm{HCl} 6 \mathrm{M}$ or $8 \mathrm{M}$, nickel was not trapped on the column as it was in the form of $\mathrm{Ni}^{2+}{ }_{\text {(aq) }}$ cation having strongly green color. The column was washed free of nickel by using corresponding concentrate $\mathrm{HCl}$. When the resin was then eluted with dilute $\mathrm{HCl}(0.05 \mathrm{M})$, no more $\mathrm{Ni}^{2+}$ was left so that the DMG spot test gave negative result. The use of $\mathrm{HCl} 9 \mathrm{M}$, on other side, showed that the formation of anion nickel complex $\mathrm{NiCl}_{4}{ }^{2-}$ has begun to take place. A part of nickel was still in the form of $\mathrm{Ni}^{2+}$ giving greenish pale color of $\mathrm{HCl} 9 \mathrm{M}$ eluate, the other part was in the form of nickel anion complex $\mathrm{NiCl}_{4}{ }^{2-}$ which was then bound in the anion exchanger resin and then changed again into $\mathrm{Ni}^{2+}$ cation form when the resin was eluted using dilute $\mathrm{HCl}$ solution, so that the DMG spot test was positive giving red coloration.

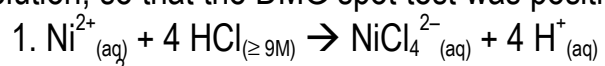

2. $\mathrm{NiCl}_{4}^{2-}{ }_{\text {(aq) }}+2$ Dowex- $\left(\mathrm{Cl}^{-}\right) \rightarrow[\text { Dowex }]_{2}-\left(\mathrm{NiCl}_{4}{ }^{2-}\right)+2 \mathrm{Cl}^{-}{ }_{\text {(aq) }}$

3. [Dowex] $]_{2}-\left(\mathrm{NiCl}_{4}^{2-}\right)+2 \mathrm{HCl}_{\text {(dilute) }} \rightarrow 2$ Dowex-(Cl- $)+\mathrm{Ni}^{2+}{ }_{(\mathrm{aq})}^{2}+4 \mathrm{Cl}_{(\text {aq) }}^{-}+2 \mathrm{H}^{+}{ }_{\text {(aq) }}$.

4. $\mathrm{Ni}^{2+}{ }_{(\mathrm{aq})}+2 \mathrm{DMG}_{(\mathrm{EtOH})} \rightarrow \mathrm{Ni}(\mathrm{DMG})_{2(\text { (red) }}+2 \mathrm{H}_{(\mathrm{aq})}^{+}$

$\mathrm{NH}_{4} \mathrm{OH}_{(g)}$

In term of the radionuclidic analysis results, the radioactive copper fractions were subjected to $\gamma$ spectrometric analysis at the range of $E_{\gamma}$ between $150 \mathrm{keV}$ to $1600 \mathrm{keV}$. The typical $\gamma$-spectrum is presented in Figure 2 as compared to the $\gamma$-spectrum of post irradiated copper solution. Both spectra seem to be very similar showing single peak at about $511 \mathrm{keV}$ as $\gamma$-annihilation radiation in accord to the data presented in Table 1. A 
very small peak which can be observed under partial magnification of the spectra shows the $\gamma$-energy of about $1346 \mathrm{keV}$ that was emitted by the radioactive $\mathrm{Cu}-64$.

\section{CONCLUSSION}

Nickel target for production of radioactive ${ }^{64} \mathrm{Cu}$ based on the nuclear reaction of ${ }^{64} \mathrm{Ni}(p, n){ }^{64} \mathrm{Cu}$ was prepared by electroplating of acidic nickel chloride solution containing boric acid on a silver-surface-target holder. The nickel target is dissolved in solution of $\mathrm{HCl} 8 \mathrm{M}$ and mixed with solution of radioactive copper from neutronirradiation of $\mathrm{CuO}$ target assuming as matrix solution containing post irradiated nickel and radioactive copper, specifically ${ }^{64} \mathrm{Cu}$ as the product of the proton irradiation of nickel target.

The simulation of $\mathrm{Ni}(\mathrm{II})-\mathrm{Cu}(\mathrm{II})$ separation procedure which had been performed in the presented study was found to be applicable as a separation method for production of radioactive ${ }^{64} \mathrm{Cu}$ based on the nuclear reaction of ${ }^{64} \mathrm{Ni}(p, n){ }^{64} \mathrm{Cu}$. The resulting ${ }^{64} \mathrm{Cu}$ was able to be separated from the post-proton-irradiated nickel matrix by means of anion exchange chromatography in which the copper was conditioned in $\mathrm{HCl} 8 \mathrm{M}$ to form tetrachlorocopperate-(II) anion, $\mathrm{CuCl}_{4}{ }^{2-}$, which was bound to the anion exchanger, while the nickel was kept in the form of $\mathrm{Ni}-(\mathrm{II})$ cation, $\mathrm{Ni}^{2+}$ which was eluted out of the column The retained $\mathrm{CuCl}_{4}{ }^{2-}$ was then eluted out from thr column as $\mathrm{Cu}^{2+}$ cation by using $\mathrm{HCl} 0.05 \mathrm{M}$.

\section{REFERENCES}

1. Http://en.wikipedia.org/wiki/Copper-64, (To be accessed on January 12, 2010).

2. M.A. GREEN, "Assessment of Cu-ETS as a PET radiopharmaceutical for evaluation of regional renal perfusion." Nuclear Medicine and Biology, 34[3] (2007) 247-255.

3. X. SUN, "In vivo behavior of copper-64-labeled methanephosphonate tetraaza macrocyclic ligands." Journal of Biological Inorganic Chemistry, 8 (2003) 217 -225.

4. J.E. SPRAGUE, "Synthesis, Characterization and In Vivo Studies of $\mathrm{Cu}(\mathrm{II})-64-\mathrm{Labeled}$ Cross-Bridged Tetraazamacrocycle-amide Complexes as Models of Peptide Conjugate Imaging Agents." Journal of Medicinal Chemistry, 50[10] (2007) 2527-2535.

5. J.S. LEWIS, "Copper-64-diacetyl-bis(N4-methylthiosemicarbazone): An agent for radiotherapy." Proceedings of the National Academy of Sciencies, 98[3] (2000) 1206-1211.

6. M.R. LEWIS, M. WANG, D.B. AXWORTHY, et al, "In Vivo Evaluation of Pretargeted ${ }^{64} \mathrm{Cu}$ for Tumor Imaging and Therapy", Journal of Nuclear Medicine, 44 [ 8] (2003) 1284-1292.

7. K.R. ZINN, T.R. CHAUDHURI, "Production of No-Carrier Added ${ }^{64} \mathrm{Cu}$ from Zinc Metal Irradiated under Boron Shielding", Cancer, 73[3] (1994) 774-778.

8. M.L. BONARDI, C. BIRATTARI, F. GROPPI, et al, "Copper-64 Production Studies with Natural Zinc Targets at Deuteron Energy up to $19 \mathrm{MeV}$ and Proton Energy from 141 down to $31 \mathrm{MeV}$ ", Proceedings of the $8^{\text {th }}$ Conference : Astroparticle, Particle and Space Physics, Detectors and Medical Physics Applications, Villa Olmo, Como, Italy, 6 - 11 October (2003) 343 - 349.

9. Y. KIM, H. PARK, J.C. LEE, et al, "A Simple Cu-64 Production and Its Application of Cu-64 ATSM", Appl. Rad. and Isot., 67[7-8] (2009)1190-1194

10. W.D. MCCARTHY, R.E. SHEFER, R.E. KLINKOWSTEIN, et al, "Efficient Production of High Specific Activity ${ }^{64} \mathrm{Cu}$ using-a-Biomedical Cyclotron", Nuclear Medicine and Biology, 24[1] (1997) 35-43

11. Http://education.jlab.org/itselemental/iso028.html (Accessed April 19, 2010)., Http://education.jlab.org/ itselemental/iso029.html (Accessed April 19, 2010).

12. Http://www.dow.com/PublishedLiterature/dh_005b/0901b8038005b46b.pdf? (Accessed April 9, 2010)].

13. S. SOENARJO, K. WISNUKATON, SRIYONO, et al, "Radionuclidic Separation of Radioactive Indium for Medical and Biological Research Applications from Target Matrix Based on Nuclear Reaction of ${ }^{\mathrm{NAT}} \mathrm{Cd}(\mathrm{n}, \gamma)$ ${ }^{115} \mathrm{Cd} \rightarrow{ }^{115 \mathrm{~m}}$ In" Journal for the Application of Isotopes and Radiation, 5[2] (2009) 147 - 164

14. D. Kopeliovich, "Nickel Electroplating" in : Http://www.substech.com/ dokuwiki/doku.php?id= nickel_electroplating (Last modified February,20, 2010) Accessed April 9, 2010.

15. G. SVEHLA, "Vogel's Qualitative Inorganic Analysis", 6th edition, Longman Scientific \& Technical and John Wiley \& Sons, Inc., New York (1987). 
16. S. SOENARJO, H. SURYANTO, SILAKHUDIN, et al, "Penggunaan Fasilitas Siklotron BATAN Untuk Produksi Talium-201", Majalah BATAN, XXV [1/2] (1992) 26 - 40.

17. WANTY, R.B., RIDLEY, W.I., WOLF, R., et al, "Separation of Copper, Iron, and Zinc from Complex Aqueous Solutions for Isotopic Measurement: Metal Sources and Processes of Acid-Rock Drainage", Paper No. 20-10, 2005 Salt Lake City Annual Meeting (October 16-19, 2005) 